\title{
The Digitalization of Wrestling Basic Techniques for Learning
}

\author{
Bambang Erawan*, Sandey Tantra Paramitha, Dadan Mulyana, Muhammad Gilang Ramadhan \\ Faculty of Sport and Health Science Education \\ Universitas Pendidikan Indonesia \\ Bandung, Indonesia \\ *bambangerawan@upi.edu
}

\begin{abstract}
The purpose of this research was to create a learning product in the form of digital Wrestling Leverage Techniques to improve the quality of learning outcomes characterized by an increase in cognitive, affective, and psychomotor abilities in the process of learning basic wrestling techniques by using a digital wrestling leverage approach. The method used in this study included two main parts, namely the analysis method, carried out through four stages: a survey of the current system, analysis of the survey findings, identification of information needs, and identification of system requirements. Data collection instruments used were divided into two activities, namely during the digitization process and the application of digitalized product results in the learning process. During the digitization process the AVS Video Editor application with an intuitive interface was used, while for measuring and knowing the results of applying digitalization activities in learning, a questionnaire for wrestling subjects was used. The document is documentation and observation. The subjects of this research were wrestling athletes who became the overall champion in the 2018 student national championship. The results of this study show that students can more easily understand and apply it properly after seeing the video that aired using the AVS Video Editor application.
\end{abstract}

Keywords: learning, basic technique of wrestling (leverage), digitalization

\section{INTRODUCTION}

Further research on basic wrestling techniques will be able to develop more comprehensive learning innovations, because wrestling needs to master the basic wrestling techniques properly and correctly. In the first year, digitizing the basic technique of Clinch Fighting wrestling has been made, this year the focus will be on digitizing the basic technique of Leverage wrestling, while in the following year digitization of the Joint Lock wrestling and Grappling Hold technique will be made. At the level of learning after applying the digitalization of the basic technique of wrestling Clinch Fighting, showing that digitalization is very innovative in the learning process, it confirms that in human life technology is developing rapidly, thus making technology increasingly common for use in various fields of activity, including in the world of education [1]. The benefits derived from digital utilization in the learning process are that learning carried out will be more effective, expanding the availability of access to information and sources of knowledge in accordance with the needs of students [2].
Efforts to realize the achievement of quality learning that is able to develop student potential requires digital applications that need to be prepared. The learning process carried out by tertiary institutions must aim to develop students' cognitive, affective and psychomotor abilities [3]. One of the important lessons in developing students' abilities is wrestling [4]. Academics currently lack attention or interest in wrestling, this is because students lack understanding of wrestling for health or martial arts. Whereas the benefits that can be obtained from wrestling are increasing self-confidence of students [5], optimizing body movements and developing student psychomotor abilities.

The urgency of developing wrestling sports digitization to include four basic wrestling techniques is expected to optimize the quality of learning of wrestling learning courses for all students who contract wrestling courses to have knowledge, attitude and skill to do the four basic wrestling movements namely Clinch Fighting, Leverage, Joint Lock and Grappling Hold [6]. As a result of the ability to master the wrestling technique, students are expected to be able to apply it in everyday life as an effort to maintain health and self-defence. The development of digitizing wrestling which includes Clinch Fighting, Leverage, Joint Lock and Grappling Hold, because each wrestling technique has different difficulties, so that each wrestling technique must be made in the form of digitization as a visual exercise media for students to understand the four wrestling techniques [7]. Efforts to optimize the visualization of wrestling techniques, then involve wrestling athletes who won POMNAS in the process of taking good and correct motion techniques to be used as a visual exercise media in the form of digitizing the learning of wrestling. Conceptually the problem of wrestling learning is the difficulty of the condition of students in the learning process at the understanding and implementation of wrestling which is characterized by obstacles in achieving learning outcomes [8]. Obstacles during the wrestling learning process can be understood as the difficulty of students to understand and apply learning material, which results in students having less interest in wrestling learning and not being able to apply it well [9]. These problems cannot be optimally realized through digitizing a basic wrestling technique, but a digitization form must be made in each basic wrestling technique. 
Technique is a way to carry out or carry out certain goals effectively and efficiently, so mastery of techniques in sports is very important in supporting the success of sports, one of which is wrestling [10]. Wrestling is a sport that uses physical contact between two people, where one wrestler must drop or can control their enemy [11]. The physical techniques shown in wrestling are clinch fight, leverage, joint lock and grappling hold. If wrong in doing this technique can cause serious injury, because of the use of this technique is closely related to premises muscle strength. In performing basic techniques (entry, slamming, rolling, locking) flexibility and flexibility, especially in joints that play an active role such as lumbar joints, neck joints and muscles that are dominantly used in wrestling sports such as leg muscles, arm muscles, abdominal muscles and in this sport is very necessary effective ability of athletes in completing matches [12]. This knowledge of wrestling style techniques must still be trained and taught in every wrestling learning.

Based on previous studies on the effectiveness of wrestling learning shows that there are errors in students doing wrestling techniques caused by not understanding the lecturer demonstration examples when demonstrating wrestling techniques. Errors due to lack of understanding of lecturer instruction resulted in during wrestling practice, students often experience injuries due to using excessive muscle movements, causing fatigue in the muscles [13]. Injuries suffered by students due to misunderstanding of wrestling movements can have long-term consequences, especially for students' careers as teachers or coaches [14]. Problems during the wrestling learning process indicate the need for innovative learning media that is more effective and efficient for students to understand and apply wrestling techniques in the learning process and in daily life that is implemented not only in one form of wrestling basic technique digitalization, but as a whole basic techniques contained in wrestling.

To support this research, researcher found the relevance article with this research, National Strength and Conditioning Association [9]. Wrestling is one of the oldest combat sports, disputed since the ancient Greek Olympic Games. This combat sport discipline has caught the attention of scientists since 1943 which is the date that matches the appearance of the first scientific research dealing with wrestling. The current short review aimed to summarize and critically analyse the scientific literature related to wrestling's physical and physiological attributes and to provide practical recommendations for testing/training together with new perspective and areas of future scientific research. Regardless of sex and wrestling styles, an optimal level of cardiorespiratory fitness is important to help sustaining effort throughout the duration of the match and to stimulate the recovery process between periods. With regard to the anaerobic power and capacity, the available studies were in agreement about their critical importance toward reaching high-level wrestling success since these variables have discriminated well between successful and lesssuccessful wrestlers regardless of age, weight classes, and wrestling styles. Physical fitness parameters such as maximal dynamic strength, isometric strength, explosive strength, and strength endurance are closely related to high-level wrestling performance. However, flexibility level seems not to be one of the key fitness variables that help to reach high-level wrestling success. Overall, to achieve high-level wrestling performance, training should be directed to develop anaerobic power and capacity, aerobic power, maximal dynamic and isometric strength, explosive strength, and strength endurance.

The purpose of this study is to improve the quality of learning outcomes for students which are characterized by an increase in cognitive, affective and psychomotor abilities in the learning process of wrestling techniques, creating learning products in the form of digitizing basic wrestling techniques, integrating learning processes with technology so that the educational process can be optimized for improve cognitive, affective and psychomotor abilities for students.

\section{LITERATURE REVIEW}

\section{A. The Era of Digitizing Education in Indonesia}

The rapidly developing digital age has resulted in technology being used in every aspect of life, including the use of applications in the world of education [15]. That is because there are many benefits that can be obtained from the use of application technology and education digitalization, ranging from making the learning process more effective, to expanding the availability of access to information and sources of knowledge that are in line with student needs. However, the important thing to understand is that digitalization can be implemented with the need for systems and applications that have been prepared, if the application cannot be accessed when needed safely and quickly, so that an application-centric strategy becomes increasingly crucial to be applied. Optimization of digitalization in education is greatly affected by the presence of good applications because it is an important factor that must be passed by users to be able to access the system and various information that is stricken [16]. The most important aspect to understand is the high demands of users for applications from time to time, it is necessary for the availability of applications that have reliable capabilities so that they can be accessed safely and quickly, so to include various elements of technology in digitizing education, IT infrastructure and systems must be prepared as the main driving machine. Changes in the world of education by utilizing digital technology innovations have occurred in Indonesia. That is because reliability, availability, and application security become important elements of the process of digitizing education, because user experience when accessing applications determines various technological innovations that are able to optimize the educational process [17]. Efforts to be able to apply an application-centric strategy, educational institutions need help from experts who have a deep understanding of applications. Educational institutions can utilize the experience and knowledge of experts who aim to ensure the availability, security, and performance of applications to find out the smooth process of digitizing education, so that learning outcomes can be maximized properly.

\section{B. The Advantages of Using Digitalization in Education}

The emergence of the digital era in education is a source of knowledge and information centre in education [18]. The impact of this is that the instructor is not the only source of 
knowledge, so students in learning do not need to be too fixated on the information taught by the lecturer, but also can access the subject matter directly from the internet, this results in lecturers not only as instructors, but also as a student guide to direct and monitor the course of the education process. At the level of learning methods, with the digitization of education brings new learning methods, which make it easier for lecturers and students to have enthusiasm and interest in the learning process. With advances in technology, new methods have been created that enable students to understand abstract materials, because these materials with the help of technology can be easily understood by students [19].

Changes also occur in the learning process because they do not have to go through face-to-face [20]. In traditional learning the learning process is conveyed only by face to face, but with advances in technology, the learning process does not have to bring lecturers and students together, but can also use digital applications. This will create student independence during the learning process. In the aspect of assessment also experienced a change, namely the existence of a data processing system of the results of the assessment using technology utilization [21]. Researchers when conducting a study, then to do an analysis of the data that has been obtained must be analysed and calculated manually, it will certainly make the learning time longer. But after the digitalization of education, all the tasks that were previously done manually and require quite a long time, become something that is easy to do.

\section{METHOD}

This research is a continuation of research from last year, last year has made the application of Clinch Fighting, in the present year will make digitization of Leverage wrestling techniques, and then in the following year focus on making the basic techniques of Joint Lock and Grappling Hold. The research schedule was carried out for 1 year because the process of making digital wrestling techniques requires a long process and test results, it was intended that the results obtained were optimal and could be used by other tertiary institutions throughout Indonesia. The place of this research would be carried out at the University of Education Indonesia (Bumi Siliwangi Stadium) for data collection from wrestling champion POMNAS, and the data is processed and made in the form of digitalization in the Department of Sports Science of the Indonesian University of Education.

The method used in this study includes 2 (two) main parts, namely the analysis method, carried out through four stages: a survey of the current system, analysis of the survey findings, identification of information needs, and identification of system requirements [22]. As for the design method, what is used is structured design through making the implementation of digital application designs. The subject of this research is to collect data from wrestling athletes who won POMNAS, it is because wrestling athletes who won POMNAS in exemplifying the basic techniques of wrestling properly and correctly. Whereas in the learning process or the application of the results of digitization of basic wrestling techniques namely Lecturers of Sports Science and Sports Sciences students of the Indonesian Education University who are contracting wrestling courses.
Data collection instruments used are divided into two activities, namely during the digitization process and the application of digitalized product results in the learning process [23]. During the digitization process using the AVS Video Editor application with an intuitive interface, this application is suitable for use in the process of digitizing basic wrestling techniques and has very complete features and is useful for video editing processes, while for measuring and knowing the results of applying digitalization activities in learning wrestling branching subjects using questionnaires, documentation and observations conducted by the research team, it is intended to know the results of the digitization process and its application in the learning process.

\section{RESULTS AND DISCUSSION}

Digitalization in wrestling is an important aspect in fostering effective and efficient ways of learning. Learning is a relatively permanent change in behaviour or potential behaviour, which owns the results of the experience and not characterized by the body while the circumstances, such as those caused by illness, fatigue or drugs [24]. Learning associated with changes in a person's behaviour to something particular situation caused by repeated experiences [25]. Learning occurs when a stimulus situation together with the contents of memory affects students in such a way that their actions (performance) change certain [26]. To exercise good wrestling with student/ athlete equipped premises $\mathrm{n}$ good basic technique. A (student / athletes) who have a good basic technique a (student / athlete) is almost can wrestle well too [27]. Some basic techniques that wrestlers need to have are clinch fighting, leverage, joint lock and grappling hold. The results of this study focus on leverage techniques.

\section{A. Basic Wrestling Technique (Leverage)}

The term leverage itself is taking advantage, so this means that a wrestler who is higher than his opponent will more easily win the fight [28]. When a wrestler gets a shorter opponent, for him it will be easy to fade out his balance and the taller wrestler will control the match. The average wrestler with a higher body has a deficiency in the strength of his opponent, so to fight it requires the use of a long range to then be able to reach the opponent's ankle [29]. With this movement, usually the tall wrestlers manage to execute well and take advantage perfectly. In the technique of grabbing the opponent's ankle, then a wrestler will be able to lift one foot off the mat and then sweep / trip the opponent's other foot so that he can finally be dropped. In this way, then automatically a wrestler can control the fight by taking advantage and being right above the body of his opponent.

1) Hip Throws: Still included in the leverage technique, hip throws are techniques that also take advantage of your opponent [30]. By way of slamming the opponent's waist, this is an effective movement for each wrestler who posture tall with long legs. After confirming the position of the opponent's upper body, footsteps can be positioned between his body to take advantage and advantage. With the waist positioned below the opponent's waist after a crossing motion, it is better to immediately take the movement of lifting the opponent's body slightly. Only then can the opponent be slammed 
of Indonesian Education, besides that as an effort to increase student independence in the wrestling learning process, students are required to look for various references regarding basic wrestling techniques to be applied during the learning process.

The design of digital wrestling basic engineering application design in sports learning conducted at the University of Education in Indonesia, can be seen from the learning process that occurs in the lecture room and practically in the field. Digitizing wrestling is done as an effort to change students' knowledge, attitudes and skills in conducting basic wrestling techniques [6]. In terms of changing students' knowledge, digitization of basic wrestling techniques includes elements of basic wrestling techniques with various effective and efficient techniques with examples from athletes who won POMNAS. To change the affective aspects of students, the focus of digital wrestling basic engineering design must contain elements that can increase motivation so that students can improve wrestling skills, while the psychomotor aspect is intended to improve student skills in wrestling, so wrestling is carried out by University students Indonesian education after contracting wrestling courses there are changes in cognitive, affective and psychomotor aspects.

\section{CONCLUSIONS}

Learning is an important aspect that exists in the academic environment. Therefore, the learning method becomes very decisive for students to be able to understand what is taught or given by a lecturer. Therefore, there is a need for innovative learning methods, one of which is digitalization. Digitalization referred to in this follow-up research is digitalization in wrestling subjects, especially on basic techniques of wrestling (leverage). In this study after students were given material about digital-based leverage techniques, students better understand and more quickly master the basic techniques of wrestling (leverage). In other words, this digital based learning method is very effectively applied to the learning of wrestling courses, especially leverage techniques for students.

\section{REFERENCES} the Indonesian University of Education, especially in wrestling learning, puts forward the cognitive, affective and psychomotor aspects. Students learn about good basic wrestling techniques and in accordance with the needs of students, the learning process is still going on traditionally without using technology as a learning medium, the learning process starts from general knowledge to strategies to do good basic wrestling techniques and effects in wrestling matches, as well as know the differences in the basic techniques of wrestling namely clinch fighting, leverage, joint lock and grappling hold conducted by national athletes [9]. After students know the various basic wrestling techniques performed by professional athletes, students must do or apply material about wrestling techniques taught by lecturers, the learning conditions that occur in the process of learning basic wrestling techniques at the Indonesian Education University. The most frequent effort made by lecturers in wrestling splitting is to improve students' psychomotor skills regarding basic wrestling techniques, because the change from psychomotor abilities is very important to improve student achievement and the University
[1] M. Khairul Anwar, "Ptofesionalisme dalam pengajaran dan pembelajaran," in Panduan amalan pengajaran dan pembelajaran berkesan, 2009.

[2] S. H. Harahap, "Pemanfaatan e-learning berbasis lcms moodle sebagai media pembelajaran untuk mata kuliah sistem informasi akuntansi," J. Ris. Akunt. dan bisnis, 2015.

[3] Sahyar, "Pengaruh Kompetensi Dosen dan Proses Pembelajaran terhadap Kepuasan Mahasiswa,” Pekbis J., 2009.

[4] A. Milanowski and S. Kimball, "The principal as human capital manager: Lessons from the private sector," in Teaching talent: A visionary framework for human capital in education, pp. 69-90, 2010.

[5] T. Goradia and A. Bugarcic, "Can self-regulated learning strategies improve academic achievement in online higher education learning environments?," Advances in Integrative Medicine, vol. 1(4), pp. 3637, 2017.

[6] J. Kantor and D. Streitfeld, "Inside Amazon: Wrestling Big Ideas in a Bruising Workplace," New York Times, vol. 15, pp. 74-80, 2015.

[7] M. Callon, "Europe wrestling with technology," Econ. Soc., vol. 33(1), pp.121-134, 2004

[8] M. S. Hanafy, "Konsep Belajar dan Pembelajaran,” Lentera Pendidik. J. Ilmu Tarb. dan Kegur., vol. 17(1), pp.66-79, 2014. 
[20] S. Assar, "Information and Communications Technology in Education," in International Encyclopedia of the Social \& Behavioral Sciences: Second Edition, 2015.

[9] H. Chaabene et al., "Physical and physiological attributes of wrestlers An update," Journal of Strength and Conditioning Research, vol. 31(5), pp.1411-1442, 2017.

[10] T. K. Scanlan and R. Lewthwaite, "Social Psychological Aspects of Competition for Male Youth Sport Participants: IV. Predictors of Enjoyment," J. Sport Psychol., vol. 8(1), 1986.

[11] W. J. Kraemer et al., "Physiological and performance responses to tournament wrestling," Med. Sci. Sports Exerc., vol. 33(8), pp.13671378, 2001.

[12] US Government - CIA, "A Tradecraft Primer: Structured Analytic Techniques for Improving Intelligence Analysis Prepared by the US Government March 2009," Intelligence, 2009.

[13] L. Halloran, "Wrestling injuries," Orthop. Nurs., vol. 27(3), pp.189-192, 2008.

[14] Z. P. Lin, Y. H. Chen, F. Chia, H. J. Wu, L. W. Lan, and J. G. Lin, "Episodes of injuries and frequent usage of traditional Chinese medicine for taiwanese elite wrestling athletes," Am. J. Chin. Med., vol. 39(02), pp.233-241.2011.

[15] W. Setiawan, "Era Digital dan Tantangannya," Semin. Nas. Pendidik. 2017, 2017.

[16] US Department of Education, "Reimagining the role of technology in education: 2017 National Education Technology Plan Update,” Off. Educ. Technol., 2017.

[17] D. Grusky, C. Goldin, and L. F. Katz, "The Race Between Education and Technology," in Inequality in the 21 st Century, 2018.

[18] M. Susanti, “Akademik Berbasis Web,” J. Inform., 2016.

[19] J. Harris, P. Mishra, and M. Koehler, "Teachers' technological pedagogical content knowledge and learning activity types: Curriculumbased technology integration refrained," J. Res. Technol. Educ., vol. 41(4), pp.393-416, 2009.

[21] P. S. Anderson, "Information and communication technology," in Encyclopedia of Earth Sciences Series, 2013.

[22] J. R. Fraenkel and N. E. Wallen, "Methodology glossary - don't cite," in How to Design and Evaluate Research in Education, 1993.

[23] A. Ghofar and S. M. N. Islam, "Research method," in Contributions to Management Science, 2015.

[24] A. Pane and M. Darwis Dasopang, "Belajar dan Pembelajaran," Fitrah Jurnal Kaji. Ilmu-ilmu Keislam., vol. 3(2), pp.333-352, 2017.

[25] E. Michaelsen and J. Meidow, "Learning," in Advances in Computer Vision and Pattern Recognition, 2019.

[26] R. A. Reiser, "Conditions of Learning," in Encyclopedia of the Sciences of Learning, 2012.

[27] S. T. Paramitha and L. E. Anggara, "Revitalisasi Pendidikan Jasmani untuk Anak Usia Dini melalui Penerapan Model Bermain Edukatif Berbasis Alam," J. Pendidik. Jasm. dan olahraga, vol. 3(1), pp.41-51, 2018.

[28] "The World of Wrestling," in Steel Chair to the Head, 2013.

[29] L. Haahr, "Wrestling with contradictions in government social media practices," in Social Media and Networking: Concepts, Methodologies, Tools, and Applications, vol. 10(1), pp.35-45, 2015.

[30] T. Cartmell, "Throwing Techniques in The Internal Martial Arts," Journal of Asian Martial Arts, vol. 18(4), 2009.

[31] M.J.R. Cerami, "Wrestling the Initiative: Ridgway as Operational Commander in the Korean War, December 1950 to April 1951," Pickle Partners Publishing, 2014. 